\title{
A Study To Determine the Basic Insulation Level Requirements for a Prototype 1200 kV CGIT Cable System
}

July 1979

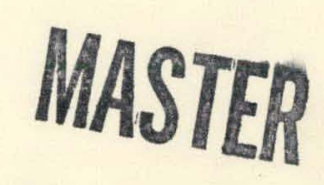

Contract No. EX-76-C-01-2061

Prepared for:

U.S. Department of Energy

Assistant Secretary for

Energy Technology

Electrical Energy Systems 


\section{DISCLAIMER}

This report was prepared as an account of work sponsored by an agency of the United States Government. Neither the United States Government nor any agency Thereof, nor any of their employees, makes any warranty, express or implied, or assumes any legal liability or responsibility for the accuracy, completeness, or usefulness of any information, apparatus, product, or process disclosed, or represents that its use would not infringe privately owned rights. Reference herein to any specific commercial product, process, or service by trade name, trademark, manufacturer, or otherwise does not necessarily constitute or imply its endorsement, recommendation, or favoring by the United States Government or any agency thereof. The views and opinions of authors expressed herein do not necessarily state or reflect those of the United States Government or any agency thereof. 


\section{DISCLAIMER}

Portions of this document may be illegible in electronic image products. Images are produced from the best available original document. 


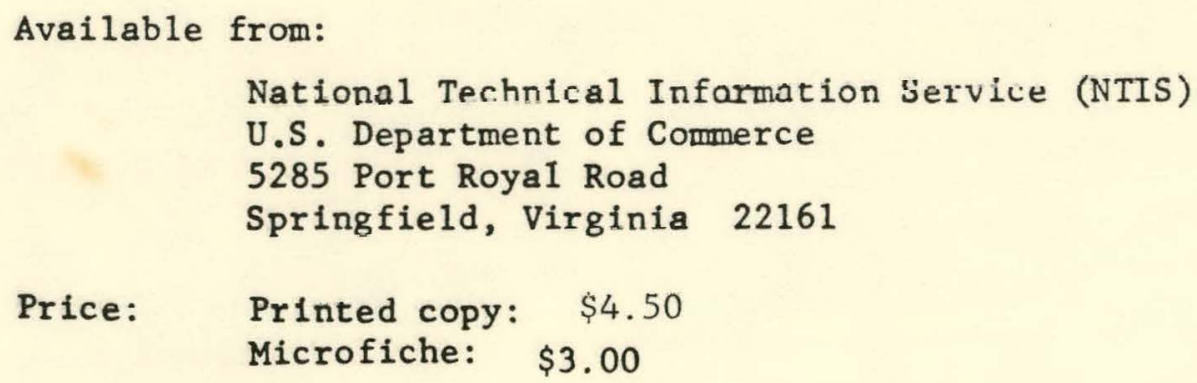


DOE/ET-2061-1

Dist. Category UC-97a

\section{A Study To Determine the Basic Insulation Level Requirements for a Prototype 1200 kV CGIT Cable System}

July 1979

Prepared by:

J. H. Cooper

Transient Analysis Engineer

Research and Development Department

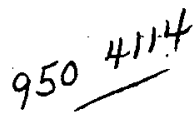

Advanced Systems. Technology

Contract No. EX-76-C-01-2061

Prepared for:

U.S. Department of Energy

Assistant Secretary for

Energy Technology

Electrical Energy Systems

Washington, D.C. 20585

This nort as an account of work sponsored by the United States Govemment. Neither the United States nor the United States Depart of their Enery nor any of their employees, hor any of their Energ subcontractors, or theis employees, makes con waronty, express or implied, or assumes any lega aly way or responsibility for the acculaus, snmplas nass liabinfy or of any information, apparatus, product or or useful disclosed, or tepresents that its use would not process disclosed, or ined rights. 


\section{NOTICE}

This report was prepared as an account of work sponsored by the United States Government. Neither the United States nor the United States Department of Energy. nor any of their employees, makes any warranty, express or implied, or assumes any legal liability or responsibility for the accuracy, completcness, or usefulness of any information, apparatus, product, or process disclosed, or represents that its use would not infringe privately owned rights. Reference hereln to any specific commercial product. process, or sevice by trade name, mark, manufacturer, or otherwise. does not necessarily constitute or imply its endorsement, recommendation. or favoring by the United States Government or any agency thereof. The views and opinions of authors expressed herein do not necessarily state or refiect those of the United States Government of any agency thereof: 
1. SUMMARY $\ldots \ldots \ldots \ldots \ldots \ldots \ldots \ldots \ldots \ldots \ldots \ldots \ldots \ldots \ldots$

2. ANALYSIS OF POSSIBLE LIGHTNING OVERVOLTAGE

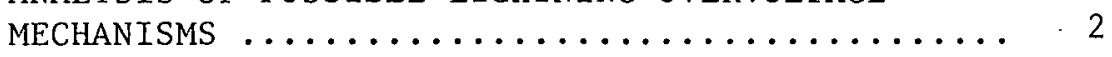

2.1 Backflashovers ................ 5

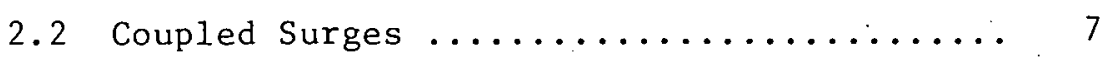

2.3 Shielding Failures $\ldots \ldots \ldots \ldots \ldots \ldots \ldots \ldots$

3. ATTENUATION AND DISTORTION OF INCOMING SURGE ... 10

4. PROBABILITY OF INCOMING SURGE $\ldots \ldots \ldots \ldots \ldots \ldots . . \ldots 12$

5. MAGNITUDE AND WAVESHAPE OF INCOMING SURGE...... 13

6. PROTECTION CRITERIA .................. 13

7. CALCUlation OF OVERVOLTAGES WITHIN THE CGIT SYSTEM ............................. 14

8. SYSTEM REPRESENTATION ..................... 15

9. RESULTS OF COMPUTER STUDIES $\ldots \ldots \ldots \ldots \ldots \ldots \ldots$

10. RECOMMENDATIONS $\ldots \ldots \ldots \ldots \ldots \ldots \ldots \ldots \ldots \ldots \ldots \ldots \ldots \ldots \ldots \ldots$

11. COMPARISON OF RECOMMENDATIONS WITH RESULTS FROM PRELIMINARY REPORT $\ldots \ldots \ldots \ldots \ldots \ldots \ldots \ldots \ldots, 22$

REFERENCES......................... 25 
A STUDY TO DETERMINE THE

BASIC INSULATION LEVÉLL REQUIREMENTS

FOR A PROTOTYPE $1200 \mathrm{kV}$ CGIT CABLE SYSTEM

1. SUMMARY

The required lightning impulse withstand characteristics of a prototype $1200 \mathrm{kV}$ CGIT System have been studied. In this study it was assumed that lightning overvoltages would be introduced into the CGIT System due to lightning strokes which terminate on the overhead transmission system connected to the CGIT system. A detailed analysis of several proposed configurations for 1100$1200 \mathrm{kV}$ transmission lines indicated that the most probable form of lightning overvoltage introduced into the CGIT System would be caused by shielding failures rather than blackflash occurrences. Following this conclusion, a single phase digital transient program was utilized to calculate the transient overvoltages which would appear within the CGIT System for system lengths of $600 \mathrm{feet}$, 2 miles, 10 miles, and 50 miles. Part of these simulations modeled surge arresters at both ends of a CGIT System representing a cable system interposed in an overhead line or a cable system terminating at an air-insulated substation. A second group of computer simulations modeled a surge arrester at one end only to represent the situation where a CGIT System terminates at a gas insulated station where the disconnects are opened and no arrester is applied within the gas insulation. Two types of surge arresters were modeled in this study: (1) an arrester having protective charactaristics extrapolated from present designs and (2) ceramic oxide arresters.

As might be expected, the most severe overvoltages occurred in the cases representing 600 foot lengths of cable. Results of these cases indicate that the CGIT System should have a minimum Basic Insulation Level (BIL) of $2425 \mathrm{kV}$ where conventional surge arresters are employed and $2050 \mathrm{kV}$ in the event that ceramic oxide surge arresters become available for protection of U.H.V. systems. BuLl of these Basic Ineulation T.pvels assume that surge arresters will be applied at both ends of the CGIT System. If surge arresters are applied at only one end of the system, the BILs would have to be increased to $2550 \mathrm{kV}$ and $2300 \mathrm{kV}$ respectively for protection with conventional and ceramic oxide arresters. A probability analysis of the lightning overvoltages which may enter the CGIT System indicated that these insulation levels should not be exceeded more than once in approximately 100 years of operation. 


\section{ANALYSIS OF POSSIBLE LIGHTNING OVERVOLTAGE MECHANISMS}

Lightning overvoltages that would be introduced into the CGIT System would be caused by lightning strokes which terminate on adjacent overhead transmission lines. Therefore, the BIL required for the CGIT System depends to a large degree on the expected lightning performance of U.H.V. transmission lines. Because of this, an important part of this study consisted of the analysis of the lightning performance of proposed U.H.V. transmission line configurations.

In order to evaluale the possibility of various lightning overvoltage mechanisms, some U.H.V. transmission line configuration had to be assumed. As a starting point, the planned 1 ine sonfiguration for Bonneville Power Administration's $1100 \mathrm{kV}$ Lyons test facility was assumed.(1) The physical dimensions of this particular configuration are shown in Figure 1 . Other pertinate data are listed in Table I. The estimated lightning performance. of this particular configuration was later compared to the lightning performance of other configurations which have been studied by a CIGRE committee on overvoltages and insulation coordination. (2)

Lightning surge voltages may be introduced onto the phase conductors of an overhead transmission line by one of four mechanisms. These mechanisms are:

1. Backflashovers - Strokes wh1ch terminate on the ground wire(s) or tower and produce voltages high enough to cause a flashover to the phase conductor.

2. Coupled Surges - Strokes which terminate on the ground wire(s) or tower but do not possess sufficient current to cause a backflash. A voltage is induced on the phase conductors due to electrostatic and electromagnetic coupling between the ground wire and phase conductors.

3. Shiplding Failuro Flaohover - Sliukes which cerminate on the phase conductor and possess sufficient current to cause a flashnver to the towcr.

4. Shielding Failures - Strokes which terminate on the phase conductor but do not possess sufficient current to result in a flashover of the conductor insulation.

The probability of occurrenre for each of the above overvullage mechanisms was studied for possible U.H.V. overhead transmission line configurations. Results of this portion of the study are summarized below. 


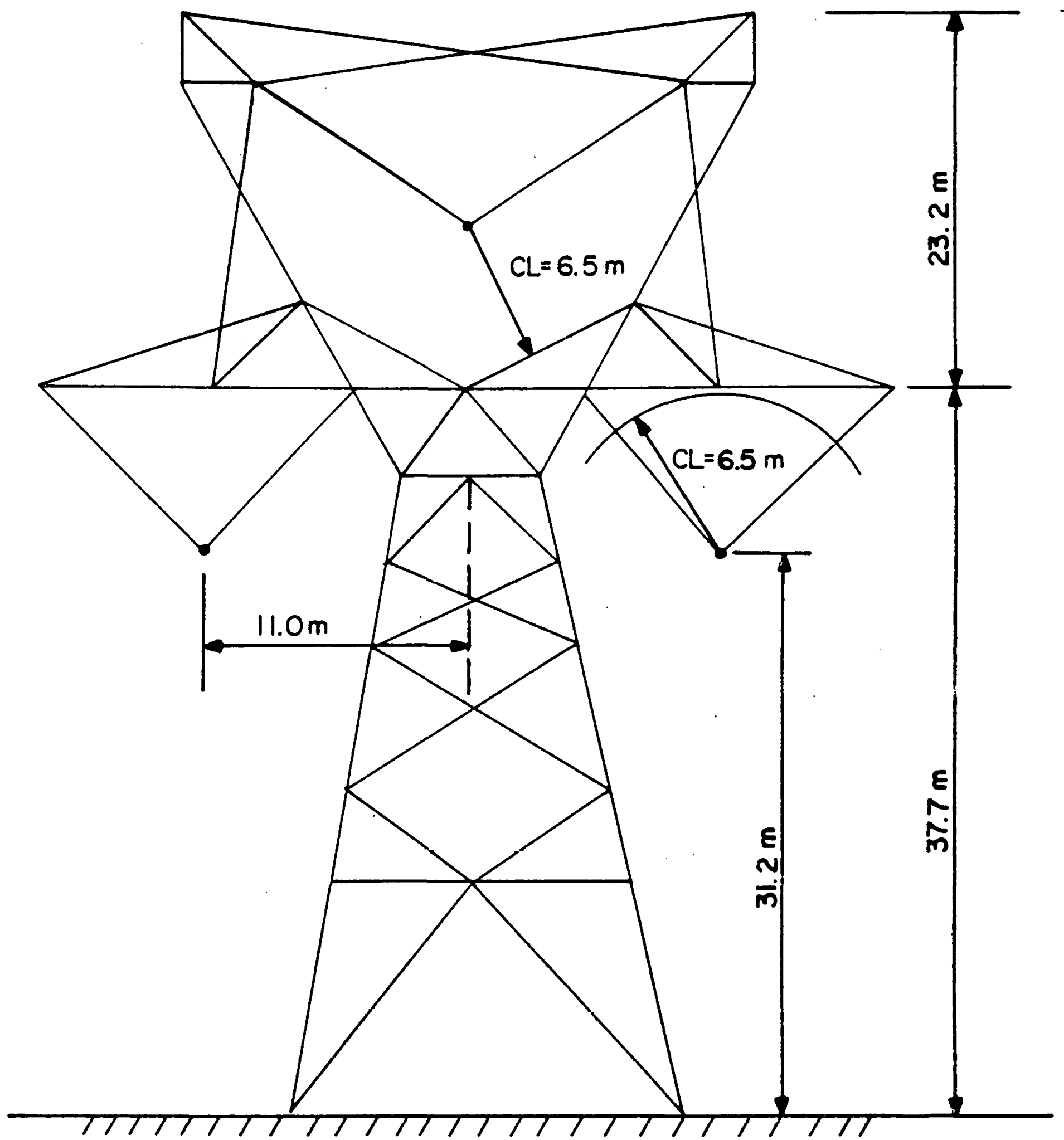




\section{TABLE I \\ Spacings and Electrical Parameters For BPA $1100 \mathrm{kV}$ Transmission Line}

1. Height of ground wires - $61 \mathrm{~m}$

2. Conductor Height at tower $-31.2 \mathrm{~m}$

3. Minimum Condurtonr Height $-23.2 \mathrm{~m}$

4. Shièidzng Angle - 50

5. Minimum Conductor to Tower Clearance $-6.5 \mathrm{~m}$

6. Number of Subconductors -8

7. Subconductor Diameter $-40.7 \mathrm{~mm}$

8. Diameter of Bundle Conductor $-107 \mathrm{~cm}$

9. Critical Flashover Voltage of Tower* - $3.64 \mathrm{MV}$

10. Three Phase Surge Impedance* - 220 ohms

11. Line-to-ground surge impedance - 276 ohms

12. Tower Footing Resistance** - 10 ohms

$$
\begin{aligned}
& * \text { - denotes calculated value } \\
& * \dot{x} \text { - denotes assumed value . }
\end{aligned}
$$




\subsection{Backflashovers}

The occurrence of a backfiash (BF) may be further divided into

the following cases:

(1) A lightning stroke to a tower which causes a sufficient potential across the phase conductor insulation to result in a flashover.

(2) A stroke to the ground wires at midspan which results in a flashover at the nearest tower.

(3) A stroke to the ground wires to midspan which possess a sufficient high current to cause a flashover of the air insulation at midspan.

To evaluate the possibility of backflashes at the towers, the critical flashover voltage (CFO) of the insulation at the towers had to be estimated. The CFO of the 6.5 meter strike distance at the towers was estimated to be $3.64 \mathrm{MV}$ from the following equation. (3)

$$
\begin{aligned}
\text { CFO }=(1.50 \mathrm{k}+380) \mathrm{d} & \\
\text { where: } \mathrm{d}= & \text { strike distance in meters } \\
\mathrm{k}= & \begin{array}{l}
\text { gap factor }=1.2 \text { for tower } \\
\text { window }
\end{array}
\end{aligned}
$$

The lightning impulse strength of the tower insulation was estimated to be $5.8 \mathrm{MV}$ at $2 \mu \mathrm{s}, 5.1 \mathrm{MV}$ at $3 \mu \mathrm{s}$, and $4.2 \mathrm{MV}$ at $6 \mu \mathrm{s}$. The equivalent surge impedance of: the two ground wires and the tower were estimated to be 314 and 170 ohms respectively. If a $200 \mathrm{kA}$ stroke current with a $3 \mu \mathrm{s}$ front time is assumed, the peak tower top voltage is approximately $3.8 \mathrm{MV}$ for a span distance of 500 meters. The voltage across the line insulation for the top phase would 'be. given by the relationship

$$
\begin{aligned}
\mathrm{V}_{\mathrm{I}}= & (1-\mathrm{C}) \mathrm{V}_{\mathrm{TT}} \\
\text { where } \mathrm{V}_{\mathrm{TT}}= & \text { tower top voltage } \\
\mathrm{C}= & \text { coupling factor between ground wires } \\
& \text { and top phase }
\end{aligned}
$$

In the case of the BPA line, the coupling factor between the ground wires and the top phase conductor is 0.36. Equation 2, predicts a peak voltage of $2.43 \mathrm{MV}$ across the tower insulation which is considerably below its $3.64 \mathrm{MV}$ CFO. The calculated tower top, and conductor induced voltage are shown in Figure 2A. Even if the lightning stroke occurs when the $60 \mathrm{~Hz}$ voltage on the conductor is at peak value and of opposite polarity, the voltage across line insulation would still remain below the insulation CFO. Calculated values for the transient voltage across the 


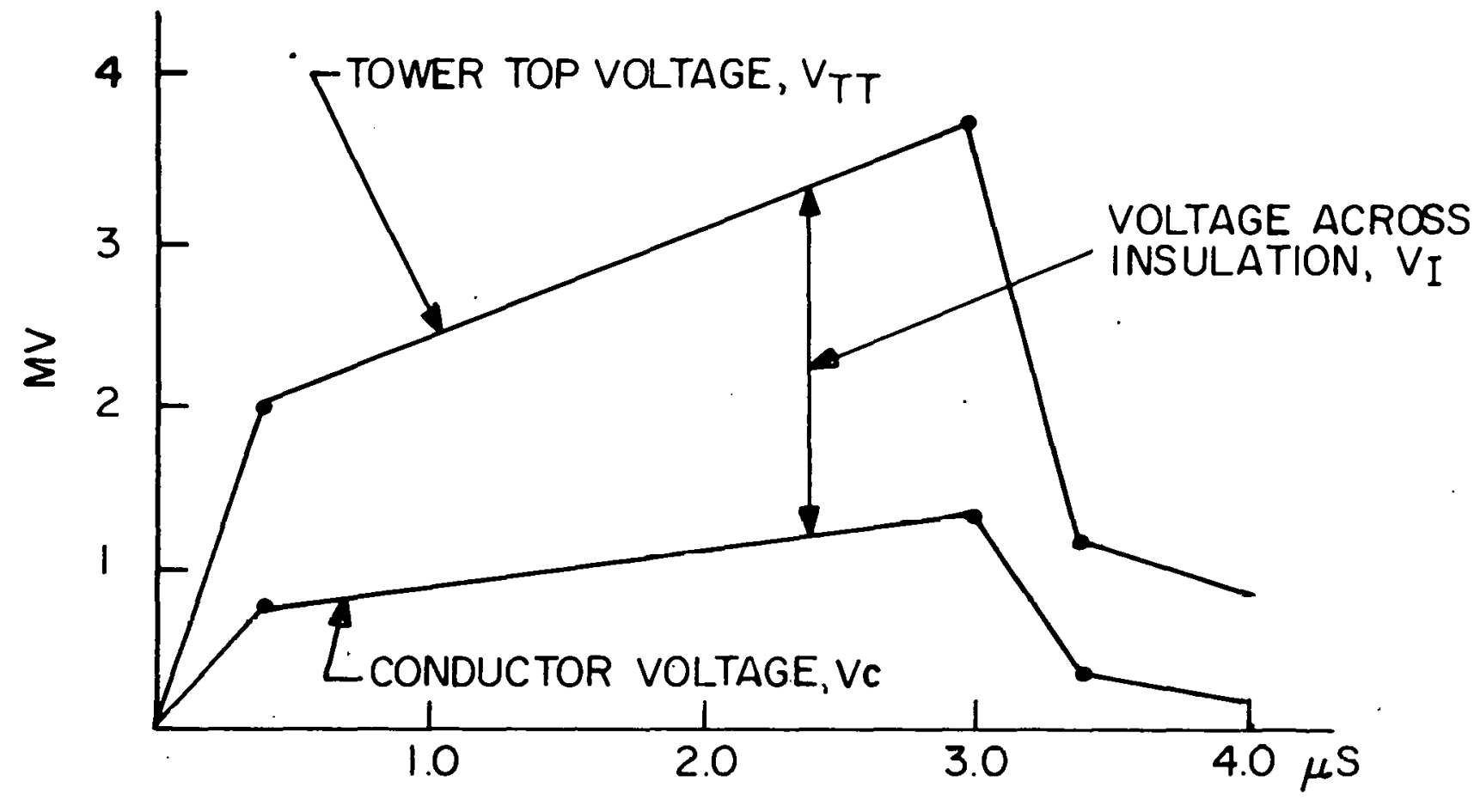

(a) $200 \mathrm{kA}$ stroke to Tower

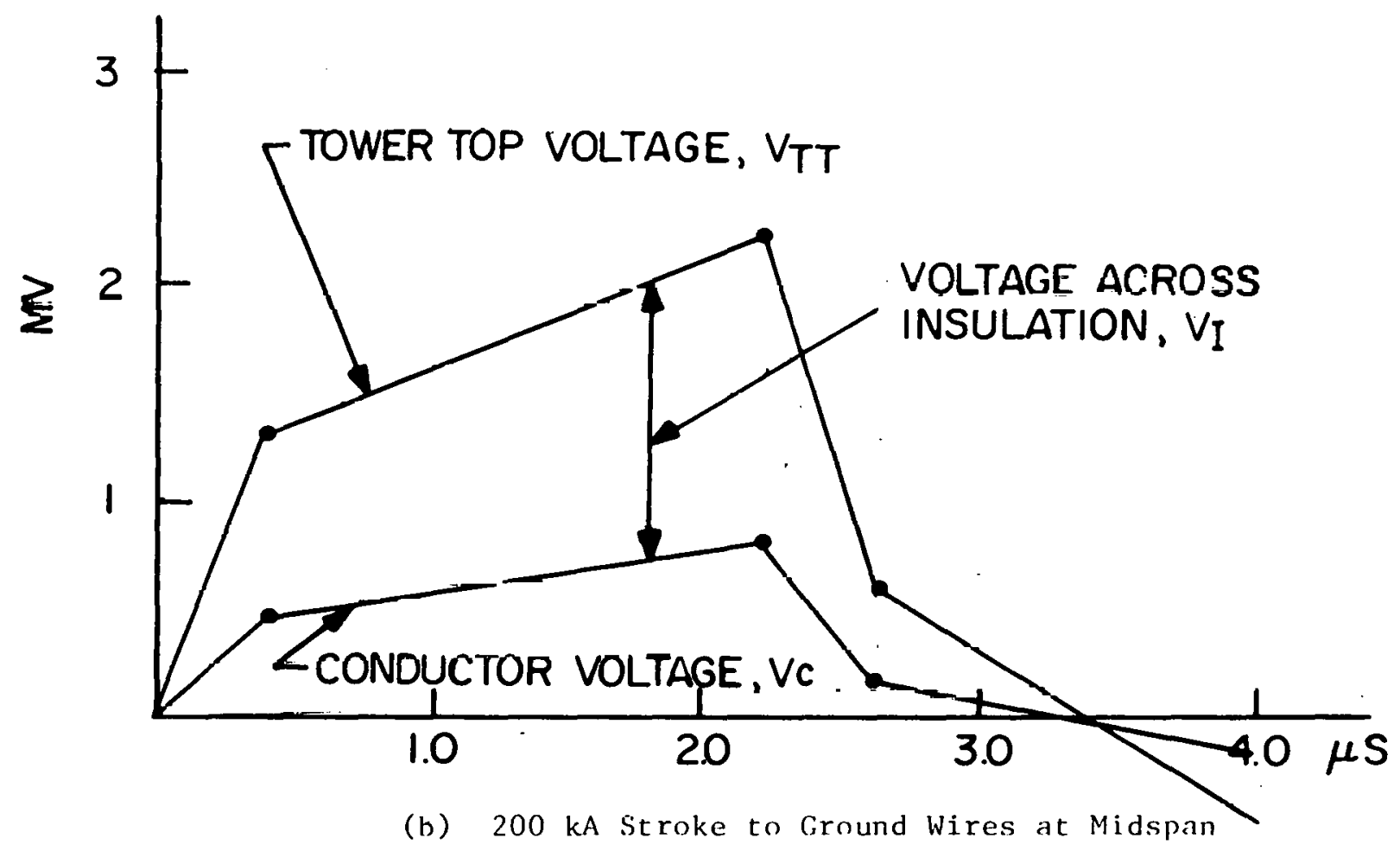

FIGURE 2 - Illustration of Surge Voltages Caused by lightning Stroke to Transmission Tower or Ground Wires 
insulation on the bottom phases yielded similar results. Because a $200 \mathrm{kA}$ lightning stroke is on the upper limit of observed stroke current magnitudes and the $3 \mu$ s front time is probably somewhat pessimistic, it was concluded that backflashes due to a stroke at the tower are very unlikely.

A similar calculation of the tower top voltage which results from a $200 \mathrm{kA}$ stroke at midspan yielded the results shown in Figure $2 \mathrm{~b}$. Since the resulting tower top voltage and voltage across tower insulation is lower than the case of a direct stroke to the tower, the occurrence of a tower backflash due to strokes at midspan is also considered negligible.

Backflashes at midspan are also considered to be very unlikely due to the predischarge phenomenon described by Wagner and Hileman. (4) It is an observed fact that midspan flashovers are rare and the possibility of this occurrence is normally neglected in lightning performance studies.

In summary, an analysis of the proposed BPA $1100 \mathrm{kV}$ transmission line indicated that the occurrence of backflash overvoltages may be neglected. This conclusion has profound implications because the highest overvoltages entering the CGIT system would probably be caused by backflashes if their possibility of occurrence were not negligible. In order to substantiate the above conclusion, a search of the literature was undertaken to see if other investigators agree with the above analysis for other U.H.V. line configurations. A comprehensive publication in this area is "Lightning Protection of UHV Transmission Lines"(2) published by the CIGRE Study Committee for Overvoltages and Insulation Co-ordination. This paper presents the results of the estimated lightning performance of a range of proposed U.H.V. transmission line configurations. Results of theoretical studies presented in this publication indicated that the backflash outage rate of proposed U.H.V. transmission lines is essentially zero over a wide range of voltages and line dimencione. The only method of analysis which predicted a non zero backflash outage rate neglected the effects of shield wire corona on the surge impedance of the shield wire system and on the coupling of this system with the phase conductors. Even with this second method of analysis, the backflash outage rates did not exceed one occurrence per 1000 years per 100 kilometers of $1000 \mathrm{kV}$ line. This outage rate was for a line configuration with a 10 degree shielding angle. It would appear that the conclusion to neglect backflash outages has support from other studies.

\subsection{Coupled Surges}

Coupled voltages will initially appear on the phase conductors at the point where lightning strikes the tower or ground wires. However, within about two or three spans the coupled voltage will decrease to zero. Therefore, the coupled surge need not be considered as a cause of lightning surge voltages at the CGIT System. 


\subsection{Shielding Failures}

The possibility of shielding failure overvoltages on the phase conductors is due to the fact that lightning strokes may bypass the ground wires and terminate directly on the phase conductors. One of the most widely accepted models for this phenomena was developed by Young, Clayton, and Hileman (5) and later modified by Whitehead and Brown. (6)

This model is based on the theory that the point at which the lightning stroke will terminate is not decided until the stroke leader comes within a distance, $r_{s}$, of the nearest ohjert at ground potential. The strike distance, $r_{S}$, is a function of the prospective istrokc current magnitude, In. An empiriral rolationshlp (2) between strike distanre and prospcctive atroke cul1tull is given by equation (3)

$$
r_{S}=9.4 I_{o}^{2 / 3}
$$

where: $I_{0}$ is in $k A$ and $r_{s}$ in meters.

This model is best explained by reference to figure 3 . For a given magnitude of stroke current the strike distance, $r_{s l}$ is determined by equation (3). Curve $a, b, c$, d shows the locus of points for a given strike distance. If a lightning stroke corresponding to this strike distance approaches the transmission line in zone $A$, it will come within the strike distance of the ground wire first and terminate on the ground wire. If the same lightning strike approaches the transmission line in zone $B$, the stroke will terminate on the phase conductor. Finally, a stroke approaching the transmission line in zone $C$ will terminate to ground. An impusldnt aspert of Lhis shlelding failure molel is that zone $B$, the widlh uf expusure, decreases to zero as the prospective stroke current increases above a certain value. From a theoretical standpoint, there is a maximum value of stroke current and, therefore, a maximum surge voltage which can appear on the phase conductor due to shielding failures. Fur the BPA line configuration the width of inpusute approachcs zero as the prospective strike current approaches $12.5 \mathrm{kA}$. Therefore, the maximum theoretical surge voltage which can appear on the phase conductor due to a shielding failure is $12.5 \mathrm{kA} / 2$ times the phase-to-ground gurge impedance. This maximum surge voltage is $1.73 \mathrm{MV}$. It should be noted that as this manilude of the prospective stroke current approaches $12.5 \mathrm{kA}$ the probability of the event occurring approaches zero.

The above analysis indicates that shielding failure overvoltages up to $1.73 \mathrm{MV}$ may occur and that no shielding fallure flashovers will occur since the CFO of the line insulation is $3.64 \mathrm{MV}$. 


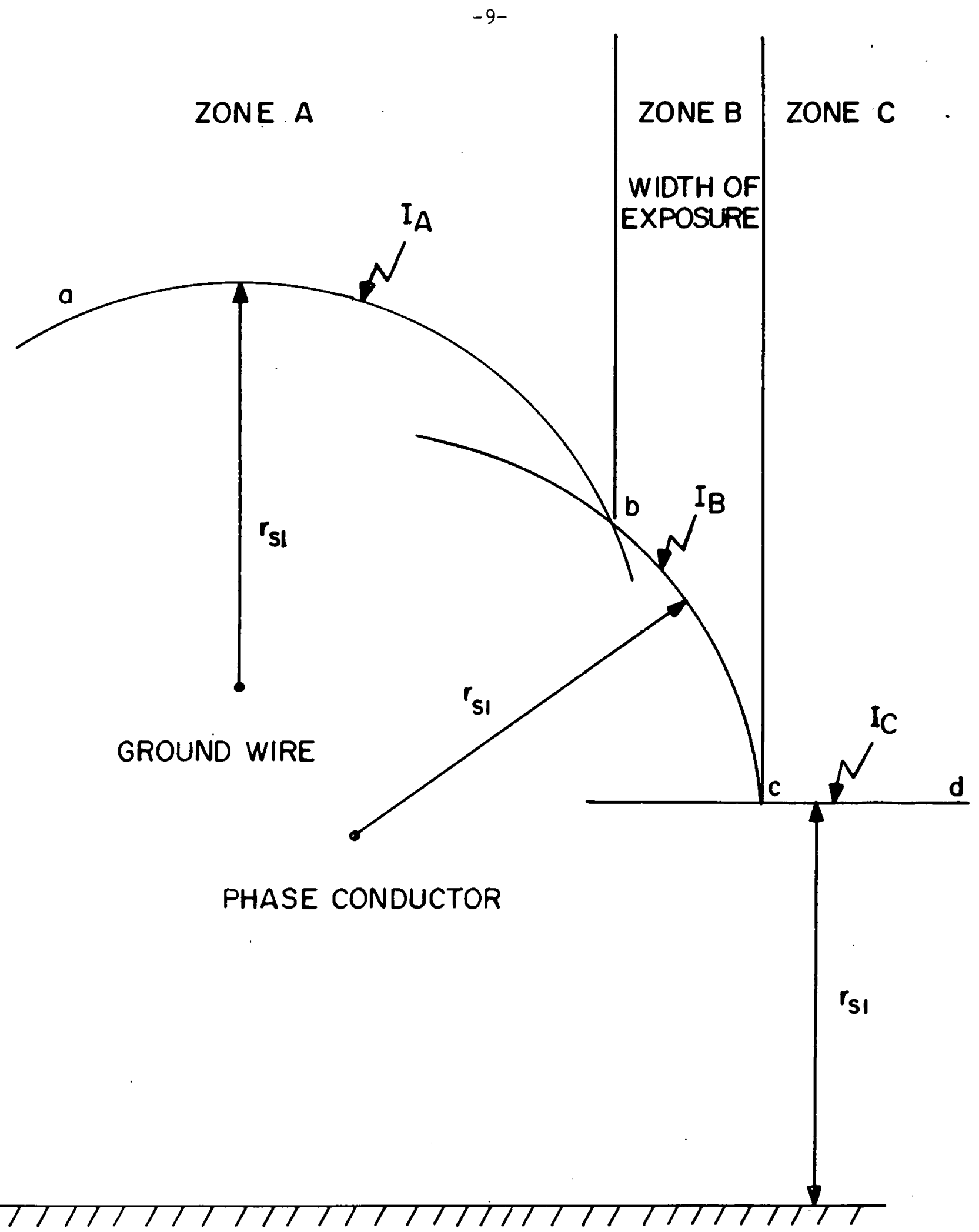

F[CURE 3 - Illustration of Shielding Failure Mechanism 


\section{ATTENUATION AND DISTORTION OF INCOMING SURGE}

In order to estimate the probability that a certain magnitude lightning overvoltage will not be exceeded at a cable-overhead line junction, the amount by which the surge is attenuated as it travels along. the line must be determined.

The phenomena which cause attenuation and distortion of traveling waves in transmission systems are listed below in the order of their importance.

1. Corona: The most pronounced cause of artenllatinn and distortion for traveling waves above the corona inception voltage, $V_{C}$, is rnrnna. The primary effect of corona is to push lack us delay that portion of the wave above $V_{C}$. Energy is released from the wave by dissipation of the wave's charge into the space surrounding the conductor.

2. Earth Resistance: Currents induced in the earth. by the surge cause appreciable losses for traveling waves whose magnitude is below the corona inception voltage.

3. Mode Propogation Distortion: Where traveling waves occur in multi-conductor systems two predominant modes of propogation exist. One mode, associated with coupling between phase conductors, travels at lie speed of 11 ght. As sccond mode assucialed with coupling to earth travels at a velocity slower than the speed of light. These two modes of propogation result in a separation of the wave's charge and an equivalent reduction in magnitude of the wave. This form of attenuation becomes appreciable halow aruld inception voltagcs.

4. Conductor Resistance: Due to skin effects the resistance of the phase conductors is much higher Lhân its d.c. resistance. However, attenuation due to sorductor resiotance is usually sindl compared to that of the earth's resistance.

To estimate the relative importance of the attenuation phenomena listed above, the corona inception voltage for a bundle conductor can be estimated with the following equation. (7)

$$
\mathrm{V}_{\mathrm{C}}=1.66 \times 10^{-3} \mathrm{nmk}_{\mathrm{d}}{ }^{2 / 3} \mathrm{r}(1+0.3 / \sqrt{\mathrm{r}}) / \mathrm{k}_{\mathrm{b}} \mathrm{C}
$$


where $\mathrm{n}=$ number of sub-conductors in bundle

$\mathrm{m}=$ conductor surface factor (normally $0.7-0.8$ )

$\mathrm{k}_{\mathrm{d}}=$ relative air density

$\mathrm{r}=$ conductor radius, in $\mathrm{cm}$

$\mathrm{C}=$ capacitance of conductor in $\mu^{\mathrm{F}}$ per meter

$\mathrm{k}_{\mathrm{b}}=$ ratio of maximum to average surface gradient

For bundle conductors

$$
\begin{aligned}
& \mathrm{k}_{\mathrm{b}}=1+2(\mathrm{n}-1) \sin (\pi / \mathrm{n})(\mathrm{r} / \mathrm{A}) \\
& \text { where A is the distance between adjacent sub- } \\
& \text { conductors in } \mathrm{cm}
\end{aligned}
$$

The above formula yields $2.27 \mathrm{MV}$ as the corona inception voltage for the BPA line configuration at standard air density. Therefore, mode propogation distortion and earth resistivity should be the predominant factors which attenuate shielding failure overvoltages on this transmission line. The following procedure was used to estimate the amount of distortion for shielding failure overvoltages.

1. The total surge voltage due to a shielding failure was split into its phase and ground mode components (i.e. fast and slow components)

2. Previous field tests ${ }^{(8)}$ showed that the ground mode component is attenuated by approximately 5.5 percent per kilometer for an earth resistivity of $100 \Omega$ meters. Therefore, the ground mode component was attenuated by this amount.

3. Separation of the unattenuated phase mode component and the attenuated ground mode component were calculated for various distances of travel.

4. The two components of the wave were added back together at the cable-line junction to determine the total magnitude of the traveling wave.

This method of analysis resulted in an overall crest attenuation of the total surge voltage of about 3 percent per kilometer for the first three kilometers of travel. 


\section{PROBABILITY OF INCOMING SURGE}

The number of shielding failures per unit length of line for a small range of stroke current $\Delta I$ may be estimated as follows:

$$
N_{S f}(I)=N_{q} L W(I) \quad f(I) \Delta I
$$

where $\mathrm{N}_{\mathrm{Sf}}\left(\mathrm{I}^{\circ}\right.$ is the number of shielding failures at a particular stroke current.

$$
\begin{aligned}
\mathrm{N}_{\mathrm{q}}= & \text { equivalent density of lightning strokes } \\
& \text { at ground level in strokes per square } \\
& \text { kilometer per year. } \\
\mathrm{I}= & \text { length of line in kllumelers. } \\
\mathrm{W}(\mathrm{I})= & \text { width of exposure for direct strokes } \\
& \text { to phase conductors as a function of } \\
& \text { stroke current. } \\
\mathrm{f}(\mathrm{I}) \Delta \mathrm{I}= & \text { probability that a given stroke will } \\
& \text { fall in the range of } \Delta \mathrm{I} .
\end{aligned}
$$

The number of shielding failures over a range of stroke currents from $I_{1}$ to $I_{2}$ would be estimated by the following summation:

$$
\mathrm{N}_{\text {sf }}=\mathrm{N}_{\mathrm{g}} \mathrm{L} \sum_{\mathrm{I}_{2}}^{\mathrm{I}_{1}} W(\mathrm{I}) \mathrm{f}(\mathrm{I}) \Delta \mathrm{I}
$$

In vides lu esclmate the total number of shielding failures over a range of stroke currents, some value of ground stroke density must be assumed or an equivalent ground stroke density can be calculated from the estimatcd number of sliukes thar will terminate on a given $1 \mathrm{cngth}$ of tranjmisyiuri liut. 'llite authors of reference 2 estimate that between 48 and 103 strokes per year will terminate on a transmission line with 60 meter high towers in an area corresponding to 30 thunderstorm days per year.

The following relationship may hr used to salculutc the cquivaleul ground stroke density assuming that the transmission line will suffor $N_{1}$ strokes per year.

$$
N_{g}=\frac{N_{l}}{T_{1}} \frac{1}{\sum f(I) \Delta I W(I)}
$$

Assuming that 100 sirokes per year per 100 kilometers will terminate on the BPA line configuration and that the current magnitudes of lightning strokes may be approximated by the AIEE (9) cumulative distrihution curve, equation 3 yields a value of 6.90 strokes per square kilometer for $\mathrm{N}_{\mathrm{q}}$. The total number of shielding failures for the BPA line configuration may then be calculated by using this value of $\mathrm{N}_{\mathrm{q}}$ and performing the summation of equation 7 from 0 to 12.5 kiloamperes (i.e. the maximum stroke current which may 
result in a shielding failure). This procedure resulted in a predicted shielding failure rate (SFR) of 2.04 strokes per year per 100 kilometers for the assumed transmission line configuration. The majority of these shielding failures would occur for low stroke currents where the width of exposure is relatively large. When stroke currents in the range from 8 to 12.5 kiloamperes are considered the expected shielding failures decreases to 0.384 strokes per 100 kilometers per year. The above SFR of 0.384 is equivalent to saying that a stroke current of 8 kiloamperes will not be exceeded in 100 kilometers of line more than once in 2.6 years. Or for a shorter length of line, say 2 kilometers, a stroke current of 8 kiloamperes would not be exceeded more than once in 130 years.

\section{MAGNITUDE AND WAVESHAPE OF INCOMING SURGE}

The characteristics of the incoming surge were based on a rate of occurrence of approximately once per 100 years of operation and attenuation characteristics described in Section 3. As described in the previous section, a lightning overvoltage rate of occurrence of approximately once in 130 years is equivalent to considering an eight kiloampere shielding failure at a distance of two kilometers from the overhead line-cable junction. Using the calculated phase-to-ground surge impedance of 276 ohms, an eight kiloampere shielding failure would result in a surge voltage of $1.1 \mathrm{MV}$. After traveling two kilometers the surge voltage would be attenuated to approximately $1 \mathrm{MV}$. A front time of 2 us was assumed for the incoming wave which corresponds to observed data for lower values of stroke current. It is important to consider that the incoming surge voltage may be superimposed on top of the peak line-to-ground $60 \mathrm{~Hz}$ voltage. In this particular case with a $60 \mathrm{~Hz}$ peak line-to-ground voltage of $980 \mathrm{kV}$, a total crest voltage of $1.98 \mathrm{MV}$ may appear at the sending end of the CGIT Syatem.

\section{PROTECTION CRITERIA}

The results of the previous sections predict that the lightning overvoltage due to an eight kiloampere shielding failure at a distance of two kilometers from the CGIT System will not be crcceded morc than once in 130 years. Thereforc, the protcction criteria employed in assessing the BIL requirements of the CGIT System were based on a $1 \mathrm{MV}$ surge entering the sending end of the system due to an eight kiloampere shielding failure originating at a distance of 2 kilometers. The cases of zero $60 \mathrm{~Hz}$ bias and maximum $60 \mathrm{~Hz}$ bias were taken into consideration. 
In order to get some measure of the sensitivity of the required BIL as a function of surge voltage magnitude, a more severe incoming surge voltage was considered which had a lower predicted rate of occurrence.

\section{CALCULATION OF OVERVOLTAGES WITHIN THE CGIT SYSTEM}

After estimating the lightning overvoltages which may enter the CGIT System from an overhead transmission line, a digital computer program was used to calculate the overvoltages within the cable.

To determine lightning surge voltage magnitudes and wave shapes within the rahle, two baoic circuits welt sludled; (1) arrcsters at cach end of lie cuble and (2) arresters at one end only. The first circuit represents a cable system interposed in an overhead line or a cable system terminaring at one air-insulated station. The second circuit represents a cable system terminating in a gasinsulated station where the gas-insulated disconnects are open and no arrester is applied within the gas-insulation.

Due to the long range nature of the CCIT project, the lightning overvoltage studies were performed assuming the most advanced surge arresters expected at the completion of this project. The two types of arresters simulated were (1) an arrester having protective characteristics extrapolated from present designs and (2) a ceramic oxide arrester. Chararteristics of a ccramic oxide arrester specified in the Westinghouse Proposal TD 75-09 to ERDA were considered to be representative of values which may be obtained in the Hedr fucure. Hrotertive rhararteristice of the two types $u$ I arreslers are listed in l'able II.

TABLE II

Surge Arrester Characteristics Used In Computer Studies

$\begin{array}{lccc}\text { Muximum Front of Wave Sparkover } & \begin{array}{c}\text { Conventional } \\ \text { Arrester }\end{array} & \begin{array}{c}\text { Ceramic } \\ \text { Oxide }\end{array} \\ \text { Maximum Impulse Sparkover } & 1990 \mathrm{kV} & 1650 \mathrm{kV} & \\ \text { Maximum Switching Impulse Sparkover } & 1766 \mathrm{kV} & 1.570 \mathrm{kV} \\ \text { Maximum 30 kA Discharge Voltage } & - & 1650 \mathrm{kV} \\ \text { Maximum 20 kA Discharge Voltage } & 2002 \mathrm{kV} & -\end{array}$


Cable lengths of 600 feet, 2 miles, 10 miles, and 50 miles were studied. The overall objective of this study was to determine the maximum lightning related overvoltages which may occur with a reasonable rate of occurrence. It was assumed that the basic insulation level of the CGIT System could be specified considering overvoltages that would not be exceeded more than once in approximately 100 years.

\section{SYSTEM REPRESENTATION}

The CGIT System was represented in the various studies by a perfect cable with a surge impedance of 60.2 ohms. It is believed that the predominant mode of attenuation for traveling waves within the CGIT System would be due to losses in conductor resistance. This assumption was made for the following reasons:

1) Corona and dielectric losses should be negligible because the dielectric is a gas and the CGIT configuration results in homogeneous electric fields.

2) The aluminum sheath should reduce ground losses to a negligible level.

3) Due to skin effect, the conductor resistance would be considerably increased at surge frequencies.

In order to simulate the increased conductor resistance at surge frequencies, the resistance of the CGIT System was calculated at $100 \mathrm{kHz}$ by means of a.c.-d.c. resistance curves for tubular conductors(10). A value of .00591 ohms per foot was used for the conductor resistance in all computer runs. The overhead line attached to the CGIT System was represented by an infinitely long transmission line (i.e. no reflections during the period of study) with a phasc to ground surgc impcdance of 276 ohmc. The accumption of an infinitely long transmission line was made because it is believed that U.H.V. lines would be at least several hundred miles long and any reflections which would return from the opposite end of the line would be negligible due to attenuation. Figure 4 gives a schematic representation of the system studied to represent a 2 mile CGIT System. Voltages at the fictitious buses 4 through 10 were monitored in addition to voltages at the sending and receiving ends of the cable to determine where the maximum overvoltages might occur within the CGIT System.

The maximum overvoltage within the various lengths of the CGIT System were determined for two different magnitudes of lightning surges, $1.0 \mathrm{MV}$ and $1.37 \mathrm{MV}$, entering the cable at the line-cable junction. The 1.0 MV surge entering the cable corresponds to a 1.1 MV surge originating at a distance of two kilometers from the cable. The probability analysis described earlier predicts that overvoltages 


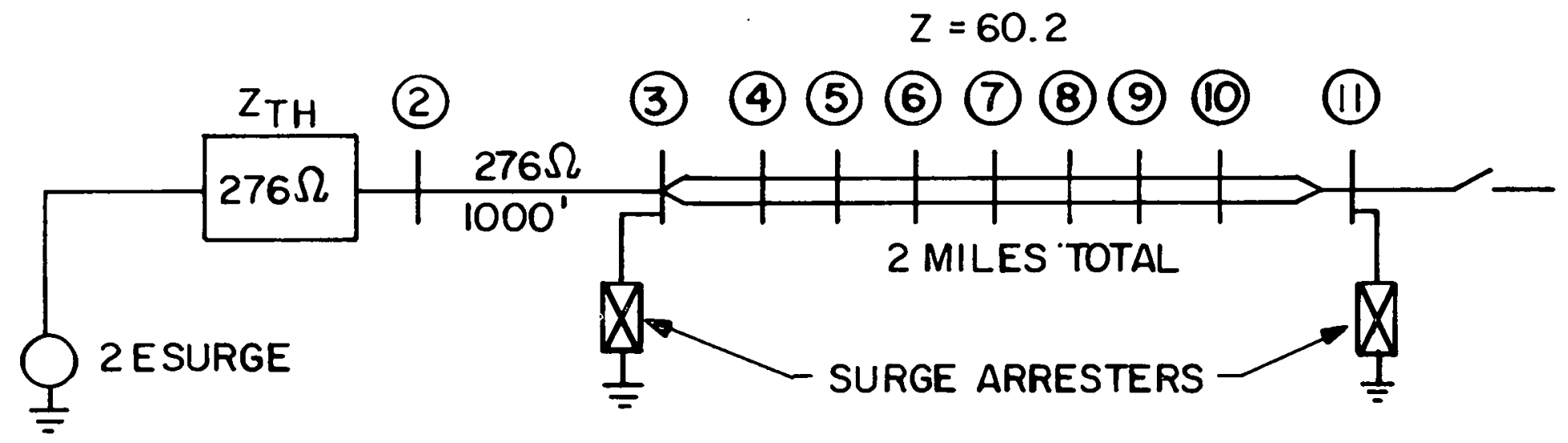

THEVENIN'S EQUIVALENT OF OVERHEAD LINE 
caused by a 1.0 MV surge entering the cable would not be exceeded more than once in 130 years. The 1.37 MV surge entering the cable corresponds to a $1.46 \mathrm{MV}$ surge originating at a distance of 2 kilometers from the cable. Overvoltages corresponding to these cases should not be exceeded more than once in 850 years.

As mentioned earlier, the situation must be considered where there is a biasing of the lightning surge voltage due to the instantaneous value of the $60 \mathrm{~Hz}$ phase-to-ground voltage. Correspondingly, three different cases were considered for each of the various CGIT System configurations.

(1) An instantaneous $60 \mathrm{~Hz}$ voltage of zero at the time that the lightning stroke occurs.

(2) An instantaneous $60 \mathrm{~Hz}$ voltage at peak value and the same polarity as the incoming surge. voltage.

(3) An instantaneous $60 \mathrm{~Hz}$ voltage at peak value and of the opposite polarity of the incoming surge voltage.

In all cases studied, the front time of the incoming surge voltage was assumed to be 2 us.

\section{RESULTS OF COMPUTER STUDIES}

The maximum overvoltages and their approximate location for each of the system configurations studied are summarized in Tables III, IV, V, and VI. Results of the cases where the $60 \mathrm{~Hz}$ voltage was of opposite polarity to the incoming surge are not presented in these tables because the resulting peak voltages were consistently below the sparkover level of the arresters. It is apparent from these results that overvoltages within the CGIT System became less severe as system length increases. This is a result of the fact that the incident wave at various points in the system decays an appreciable amount in the longer systems before reflected waves return from the ends of the cable. The results also tend to indicate that for CGIT System lengths of 10 miles or greater the surge arresters have little etfect on the maximum lightning overvoltages. This is because the maximum overvoltages approach the value of the surge arrester sparkover voltages for system lengths over 10 miles. Another significant result is that the required BIL levels for the CGIT System are relatively insensitive to the expected rate of occurrence. That is, the maximum overvoltages within the CGIT System are not significantly different for a rate of occurrence of once per 130 years and once per 850 years. 
TABLE III

Overvoltages Within CGIT for 1.1 MV Surge

Originating at 2 Kilometer Distance

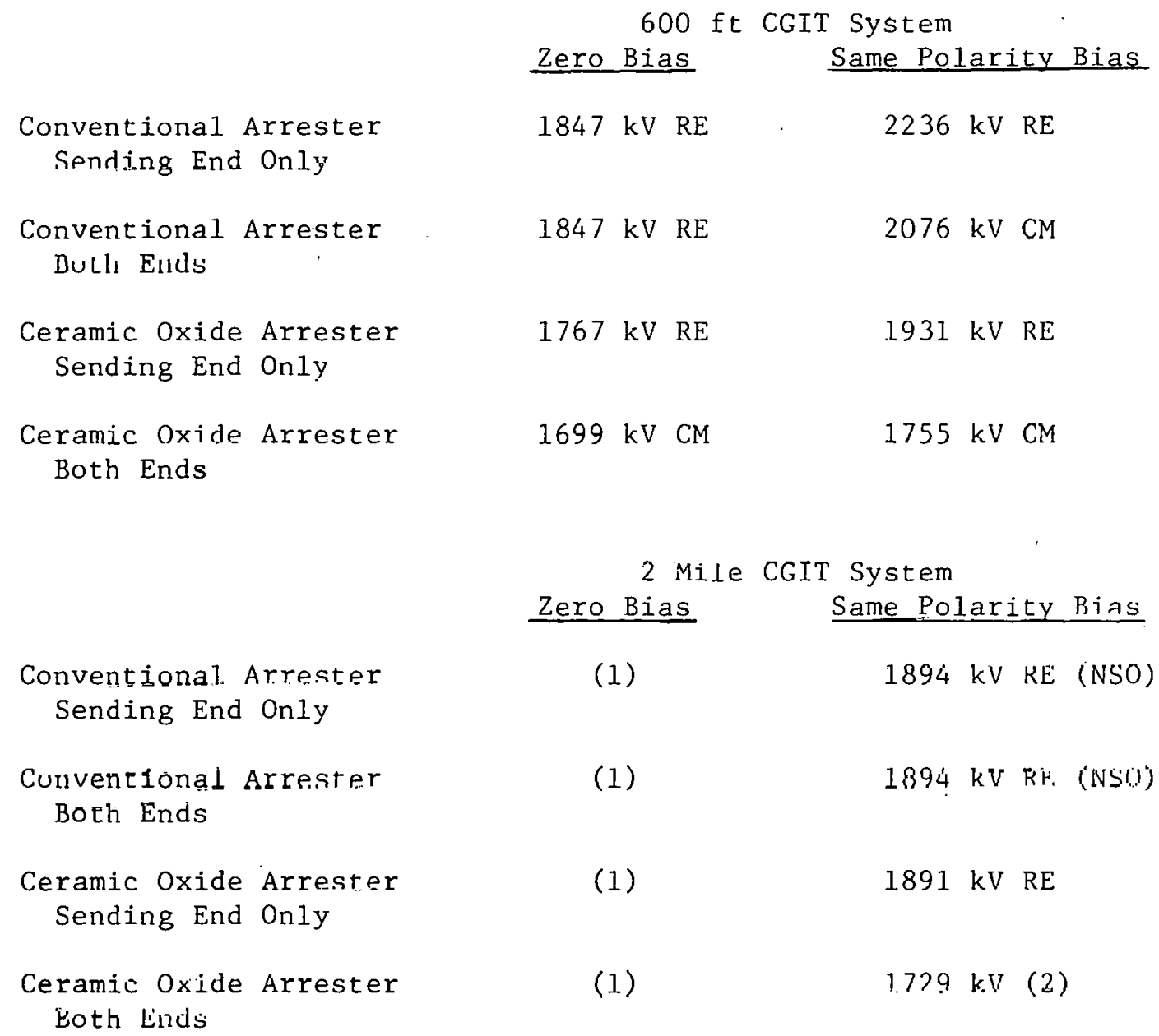

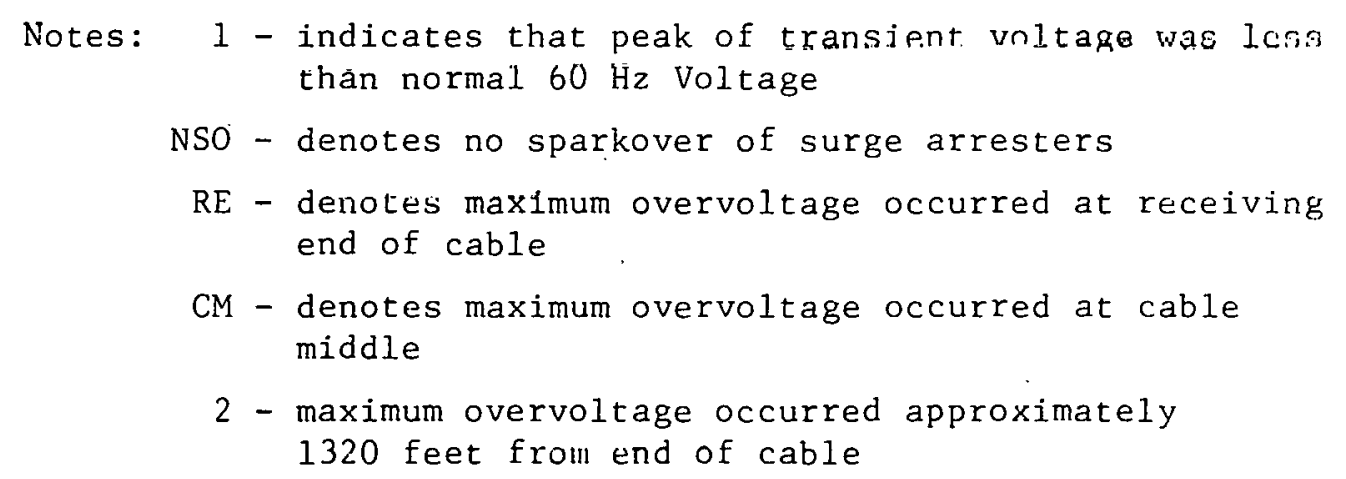


TABLE IV

Overvoltages Within CGIT for 1.1 MV Surge

Originating at 2 Kilometer Distance

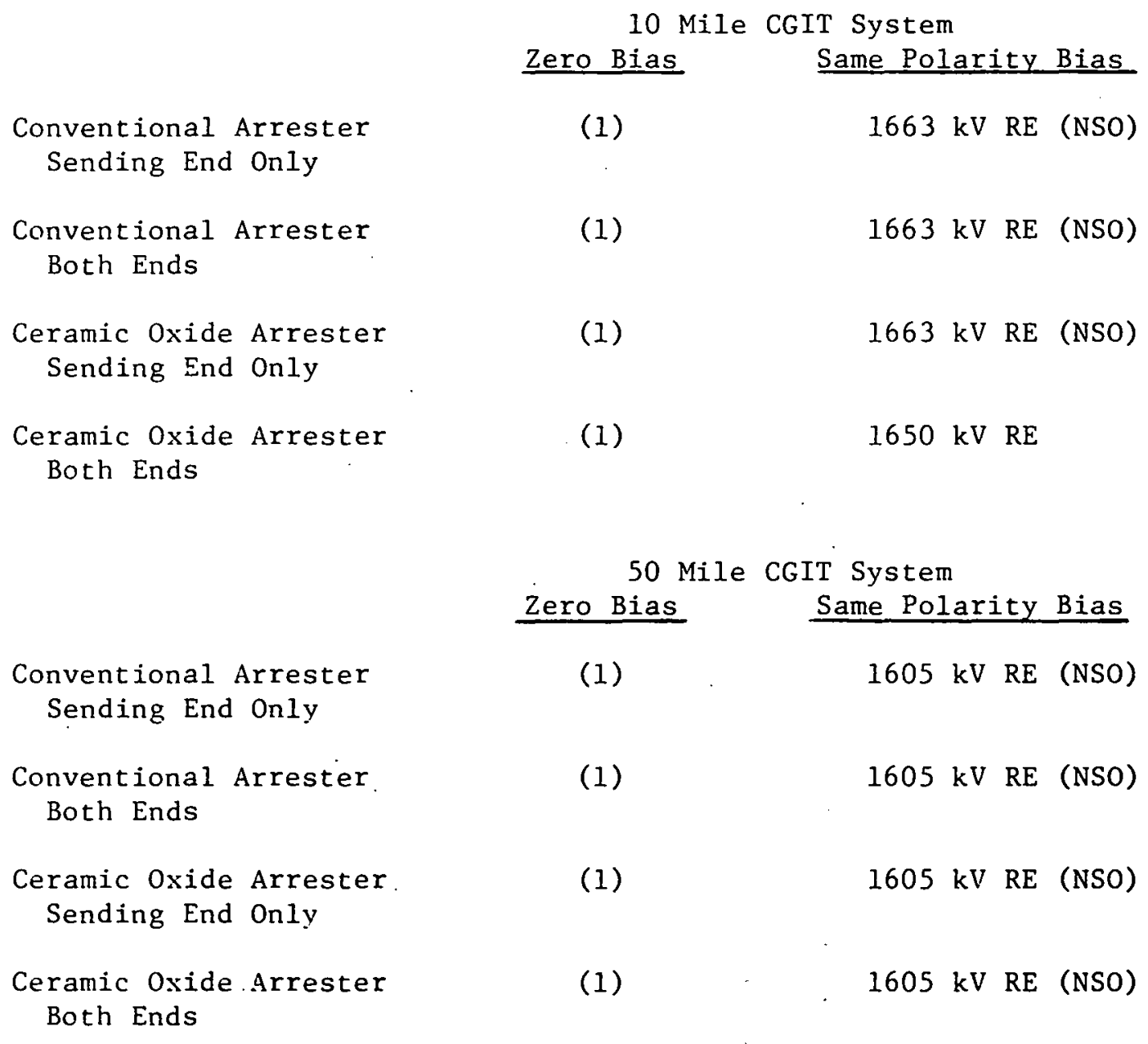

Notes: 1 - indicates that peak of transient voltage was less than normal $60 \mathrm{~Hz}$ Voltage

RE - denotes maximum overvoltage nrrurred at. receiving end of cable

NSO - denotes no sparkover of surge arresters 


\section{TABLE V}

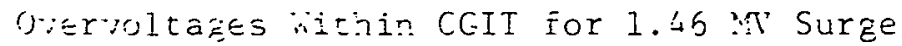

Orieinating at 2 Kilometer. Distance

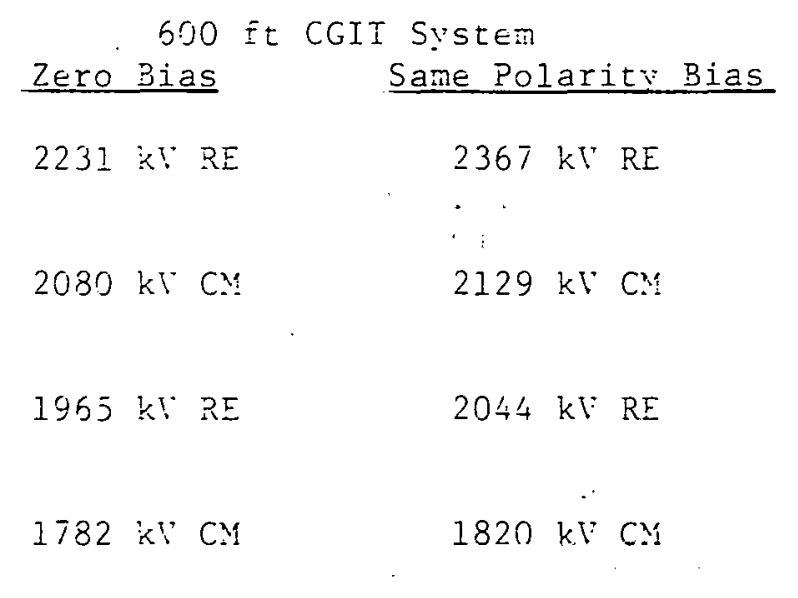

Conyentional Arrester

Sendinë End OnI?

Conventional irrester Bol: Ends

Ceraric oxide Arrester $\therefore \therefore$ Sending End Onl?

Ceramic Oride arrester Eoth Ends

2 Yille CGIT System

Zero Bias Same Polarity Bias

Conventional Arrester

Sending End Only

Convell Jumad Arrester

Both Fnda

Ceramic Oxide Arrester

Sending End Only

Ceramic Dxide Arrester

Both Ends
(1)
$2308 \mathrm{kT} R \mathrm{RE}$

$2064 \mathrm{kl}:(2)$

$2130 \mathrm{kV} \mathrm{RE}$

$1886 \cdot \mathrm{kl} \cdot(2)$ 
TABLE VI

Overvoltages Within CGIT. for $1.46 \mathrm{MV}$ Surge

Originating at 2 Kilometer Distance

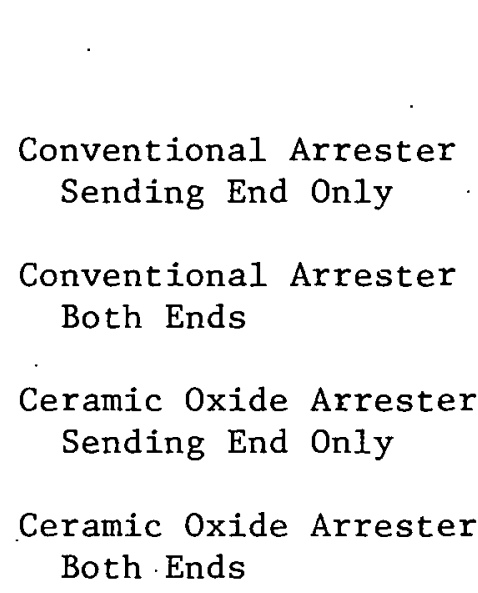

Conventional Arrester Sending End Only

nventional Arrester

eramic Oxide Arrester

Ceramic Oxide Arrester Both . Ends

\author{
10 Mile CGIT System \\ Zere Bias. \\ Same Polarity Bias \\ (1) \\ $1936 \mathrm{kV} \mathrm{RE} \mathrm{(NSO)}$ \\ (1) \\ $1936 \mathrm{kV} \mathrm{RE} \mathrm{(NSO)}$ \\ (1) \\ $1936 \mathrm{kV} \mathrm{RE}$ \\ (1) \\ $1650 \mathrm{kV} \mathrm{RE}$
}

50 Mile CGIT System

Zero Bias

Same Polarity Bias

Conventional Arrester

Both Ends

Ceramic Oxide Arrester

Sending End Only

Ceramic Oxide Arrester

Both Ends
(1)

$1852 \mathrm{kV} \mathrm{RE} \mathrm{(NSO)}$

(1)

$1852 \mathrm{kV} \mathrm{RE} \mathrm{(NSO)}$

(1)

$1852 \mathrm{kV} \mathrm{RE} \mathrm{(NSO)}$

(1)

$1650 \mathrm{kV} \cdot \mathrm{RE}$ 


\section{RECOMMENDATIONS}

With the assumptions discussed earlier in the report about the possible mechanisms of lightning overvoltage occurrence and a protective margin of approximately 15 percent, the BILs 1isted in Table VII would be adequate for shorter lengths of CGIT Systems. Values in this table were chosen considering ANSI preferred values for transient insulation levels(11) and an overvoltage rate of occurrence of once in 130 years.

For CGIT System lengths of 10 miles or greater, a BIL rating of. $1925 \mathrm{kV}$ should be adequate regardless of the number or type of arresters selected.

\section{COMPARISON OF RECOMMENDATIONS WITH RESULTS} FROM PRELIMINARY REPORT

Results of a preliminary study to determine insulation levels for the CGIT. System were presented in the first quarterly report associated with ERDA Contract E(49-18)-2061. Tn farilitate comparison, the range of BIL's from this report are shown in Table VIII.

\section{TABLE VIII}

Range of $1200 \mathrm{kV}$ CGIT Insulation From Preliminary Report Lightning Impulac Level
(BIL)

Minimum

Medium

Max inum

\author{
Céramic osile \\ Arrester
}

$1980 \mathrm{kV}$ $2145 \mathrm{kV}$

$2310 \mathrm{kV}$
$864 \mathrm{kV}$ Conventional Arrester

$2.594 \mathrm{k.V}$ $2810 \mathrm{kV}$ $3027 \mathrm{kV}$

These values were determined for a CGIT System length of approxinately 2000 feet with surge arresters applied at both ends. The medium values were obtalncd from a simplified traveling wave analysis while the other values were based on approximate methods used for other types of substation equipment. Therefore, the recommended BILs from this report should be compared with the medium range values from the preliminary report. A comparison of these values indicates that the recommended values from the detailed analysis of this report are slightly lower than those from the preliminary study. This is mainly due to the following reasons: 
TABLE VII

Recommended BIL For CGIT System

600 Foot System With Surge Arrester at One End Only

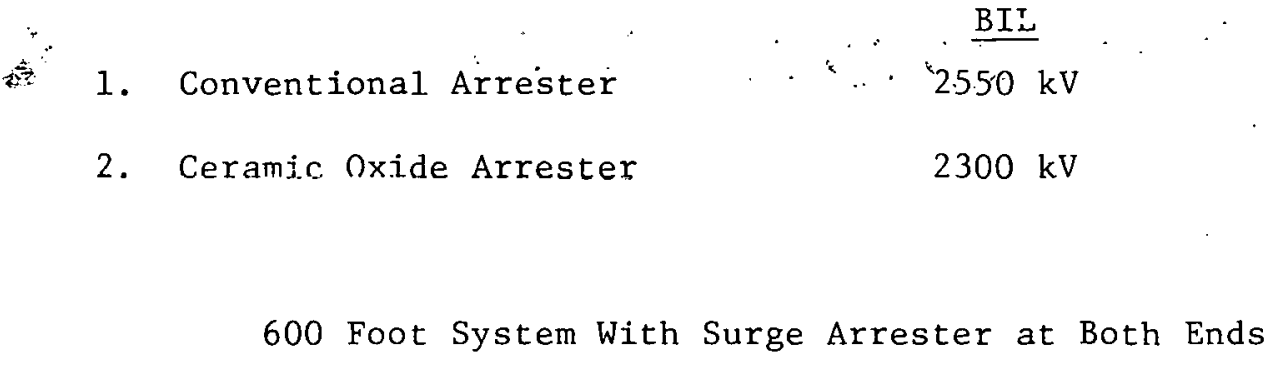 \\ 1. Conventional Arresters $2425 \mathrm{kV}$ \\ 2. Ceramic Oxide Arresters $2050 \mathrm{kV}$
}

2 Mile System With Surge Arrester at One End Only

1. Conventional Arrester $2175 \mathrm{kV}$

2. Ceramic Oxide Arrester $2175 \mathrm{kV}$

2 Mile System With Surge Arrester at Both Ends

1. Conventional Arresters $2175 \mathrm{kV}$

2. Ceramic Oxide Arresters $2050 \mathrm{kV}$ 
1. The preliminary report arbitrarily assumed an incoming $3 \times 20$ us lightning voltage with a crest value of 3 MV while the method of analysis in this report assumed a $2 \times 50 \mu \mathrm{s}$ incoming wave with a crest value of $1 \mathrm{MV}$. The incoming wave in this report was estimated from the lightning performance of proposed U.H.V. transmission lines.

2. A sparkover ievel of $2050 \mathrm{kV}$ was used to model conventional arresters in the preliminary study compared to a sparkover " value of $1990 \mathrm{kV}$ used in this report.

Another difference in the two methods of analysis was that the instantaneous value of the $60 \mathrm{~Hz}$ voltage was neglected the preliminary study. 


\section{REFERENCES}

1. Annestrand, S.A., and Parks, G.A., "Bonneville Power Administrations Prototype 1100/1200 kV Transmission Line Project," Presented at IEEE 1976 Summer Power Meeting.

2. CIGRE Study Committee No. 33 - Overvoltages and Insulation Coordination, "Lightning Protection of U.H.V. Transmission Lines," ELECTRA, No. 41, pp. 39-69, 1975.

3. Leroy, G., Gallet, G., Kosztaluk, R., and Kromer, I.L., "Ultra High Voltage Overhead Networks: Determining of Insulation Distances," Revue Generale de Electricite, pp. 27-44, June 1974.

4. Wagner, C.F., and Hileman, A.R., "Effect of Pre-discharge Currents on Line Performance," IEEE Transactions on Power Apparatus and Systems, Vol. 82, pp. 117-131, 1963.

5. Young, F.S., Clayton, J.M., and Hileman, A.R., "Shielding of Transmission Lines," TP 63-640, IEEE Transactions, Special Supplement, Power Apparatus and Systems, p. 132, 1963.

6. Brown, G.W., and Whitehead, E.R., "Field and Analytical Studies of 'l'ransmission Line Shielding-II," IEEE Transactions on Power Apparatus and Systems, Vo1. 88, pp. 617-626, 1969.

7. Diesendorf, W., Insulation Coordination in High-Voltage Electric Power Systems, Butterworths, 1974.

8. Wagner, C.F., Gross, I.W., and Lloyd, B.L., "High-Voltage Impulse Tests on Transmission Lines," AIEE Transactions Pt. III, Vol. 73, pp. 196-210, 1954.

9. AIEE Committee Report, "A Method for Estimating Lightning Performance of Transmission Lines," AIEE Transactions Pt. III, Vol. 69, pp. 1187-1196, 1950.

10. Zaborszky, J., and Rittenhouse, J.W., Electric Power Transmission, Rennsselaer Bookstore, 1969.

11. American National Standards Institute, Voltage Values for Preferred Transient Insulation Levels C92.1-1971. 